\title{
ECONOMIC REGULATION AS A REQUIREMENT FOR ECONOMIC EFFICIENCY: THE ASSESSMENT OF TURKEY
}

\author{
Ali Fuat URUŞ ${ }^{1}$
}

\begin{abstract}
Macroeconomic priorities of today's states are efficiency in resource allocation, economic stability and development. For these purposes, the state assumes the role of regulator. By means of economic regulation arising from the need for economic efficiency, the state prevents the monopolization and market inefficiency by creating the legal framework of competition in order to ensure and preserve the free competition in the markets. It also assures the continuity of competition in the market economy by using control,audit and sanction mechanisms. The purpose of this study is to put forth the conceptual dimensions of economic regulation and its application in Turkey as a general outline within the framework of economic efficiency. For this aim, a literature review and some evaluations were made. Considering the economic regulation practices in Turkey, it was found to have shortcomings on issues such as in-market competition, pricing and costs at the point of ensuring the economic efficiency and competitiveness in the market. It is important to design a system to achieve public benefit through relevant regulation institutions in the markets such as finance, capital, banking, energy, telecommunication and transport which are key in the national economy. For this purpose, the limit of the duties and responsibilities undertaken by regulation institutions in order to correct the disruptions of the market and to establish the competition should be clarified by the laws and rules. Furthermore, the existing regulation, and especially economic regulation practices in Turkey -taking into consideration the results of similar practices in other countries- should be revised in the context of "globalization, privatization and competition" phenomenons then, according to this point of view reasonable regulatory policies should be identified and implemented by sectoral base.
\end{abstract}

Keywords: Public Economics, Regulation, Economic Regulation, Economic Efficiency

JEL Code: H30, K20, L51, H13.

\section{Introduction}

The regulatory function of the state is carried out through regulation. We see that the state uses often the regulations as a form of intervention when the market does not provide efficiency by itself or the market is unsuccessful. It is possible to say that the state aims to effectively allocate resources through regulations, and therefore economic regulation is used as a requirement of economic activity.

Aim of this study to put forth the conceptual dimension of economic regulation and the general outline of its application in Turkey in the framework of economic efficiency. So, a literature review and some evaluations were made.

\footnotetext{
1 Res. Asst., İzmir Kâtip Çelebi University, Faculty of Economics and Administrative Sciences, Department of Public Finance, alifuat.urus@ikc.edu.tr
} 
In the study respectively; efficiency and economic efficiency concepts, conceptual perspective of economic regulation, the relationship between economic regulation and economic activity,assessment of the transition to economic regulation in Turkey were discussed. In this context, determinations and suggestions were made.

\section{Efficiency and Economic Efficiency Concepts}

The concept of activity is expressed as the absence of waste and is explained by a distinction in the form of static-dynamic. Static efficiency; $X$ efficiency is divided into two as activity and resource allocation. $X$ efficiency ${ }^{2}$, the presence of effective management in the company and expresses the state of error and laziness; resource allocation efficiency refers to the situation in which resources are allocated in such a way as to ensure the equality of the prices for each company and every goods to the marginal cost. Dynamic efficiency is a criterion that expresses the optimum technical composition, which occurs when resources are effectively allocated for innovation and inventions, and inventions do not postpone specific gains (Akça, 2007: 23).

In general, while the concept of efficiency can be explained in this way, economic efficiency ${ }^{3}$ can be defined as maximizing the welfare by providing optimum resource distribution in free market system. In order to ensure economic efficiency, the distribution of resources (efficiency in distribution) and production should be carried out effectively (efficiency in production). The mechanism to do this is the functioning of competitive markets. Indeed, in the long term, it can be seen in competitive markets both "efficiency in production" (achieved by reducing costs to a minimum) and "efficiency in distribution" (consumer demands met with price reflecting costs)(Ardıyok, 2002: 10; Çakal, 1996: 7). General efficiency is provided when both activities are provided simultaneously.

\section{Conceptual Perspective Of Economic Regulation}

In today's democratic societies, the state has the functions of ensuring efficiency in resource utilization and distribution and ensuring economic development and stability. The realization of these functions is possible by providing free competition in the markets. Therefore, it is the duty of the state to take measures for the formation and protection of competition in the markets, to establish the legal framework and to provide supervision.These duties of the states reveal the result of the formation of "economic regulation" (Pervan, 2006: 14).

Economic regulation can be defined as the methods developed by natural monopolies in order to eliminate the negativities created by natural monopolies and to provide economic efficiency and to intervene in these markets by various institutions in order to eliminate market failures (Erol, 2003: 23).In terms of economic regulation, the state can put restrictions on the decisions of firms in the sector in order to ensure competition in the market. These limitations, as well as the price of the product, can be about the amount of the state and the market entry and exit can also keep the state under control (Sarisoy, 2010: 281).

\footnotetext{
2 Leibenstein $(1966,1975)$ stated that individuals and firms work under normal conditions for a number of reasons and are not working efficiently, therefore firms and economies cannot operate on the production possibilities curve that they can realize in accordance with their resources, he stated that he was high and important and he defined this situation as "X-inefficiency".

3 For detailed information on economic efficiency and its types, see. Kirmanoğlu, 2011: 63-70.
} 
After the crisis in 1930s, the main aim of the regulatory state, which occurred especially during the Second World War, was to manage the economy. At present, the vast majority of current regulatory authorities and rules have been influenced by the ideas that occurred in that period or later in that period. These regulations for improving the efficiency of the markets are called "economic regulation". As an example of economic regulation; price, wage (such as minimum wage), rent, interest rate and exchange rate controls, prevention or limitation of access to the market, providing incentives to public institutions and private institutions, etc. applications. Economic regulation aims to ensure the effectiveness of the markets by creating rules for adequate competition among the existing actors in the market or by setting rules that will make them behave similar to the behaviors they would demonstrate if they were competitive (Tepe\&Ardıyok, 2004: 108-109).

Although it is said that there have been regulations since the day the state existed, it can be said that the scientific debates on economic regulation started in the USA in the 1800s and the discussion of it in the economic literature has increased since the 1970s (Sarısoy, 2010: 295-296).

\section{Relationship Between Economic Efficiency And Economic Regulation ${ }^{4}$}

Market failures for the existence or emergence of economic regulation are indicated. Because economic regulation is one of the intervention tools used by the state to eliminate market failures. Therefore, the primary objective of economic regulation should be to eliminate market failures (Akça, 2007: 22). From this point of view, it should be the main objective to ensure economic efficiency, whether for the purpose of public interest or for personal benefit. That is, the starting point of economic regulation is based on market failures around the purpose of public interest. Market failure indicates inefficiency in resource allocation. This inefficiency can be eliminated by economic regulation. In other words, an effective economic regulation is needed in order to eliminate the welfare losses caused by inefficiency (Akça, 2007: 121-122).

Economic regulation can be considered as a two-stage process. In the first stage, the objectives of the regulation are determined; In the second stage, an environment is created to achieve this goal and the most appropriate methods are developed (Uğurlu, 2007: 27). In other words, economic regulation tries to achieve an optimum solution by providing a balance between economic efficiency and economic sustainability. In the second step after the optimum solution is determined, it is necessary to identify the most appropriate means to achieve this goal. Although the most important tool of economic regulation is tariff (price, wage etc.), it cannot be said that it is limited to tariff. It has a wider application area including some other elements such as market entry-exit, quality regulation (Uğurlu, 2007: 28).

The relationship between economic activity and economic regulation is to summarize the use of economic regulation to eliminate inefficiency in resource allocation due to market failure. In other words, it is the use of economic regulation to eliminate economic inefficiency and to ensure efficiency.

\footnotetext{
4 Several debates and opinions were made on the relationship between economic activity and economic regulation. In this context; SeeDemsetz (1969), Stigler (1976), Williamson (1979), and Becker (1983). Akca, 2007: 122-123.
} 


\section{Evaluation Of The Transition To Economic Regulation In Turkey}

In Turkey (economic) history of the regulation of the practice, considered as two different periods. The first period is a period in which the state establishes its own market by producing goods and services and the private enterprise is limited. The second period is the period in which the state is dealing with the control of the markets without being involved in the production process. Second, although the more recent period, Turkey is the first period that dominated the economic history (Oğuz\&Çakmak, 2002).

The processes related to economic regulation in Turkey, located roughly summarize the overall assessment and, if necessary, mixed economic system implemented in Turkey until the 1980s, a little more visible after this date is passed to the market economy. Until then, public services carried out by the public have been carried out by the private sector through privatizations. With the transfer of these public services, which are predominantly of natural monopoly, to private sector, private monopolies were replaced by public monopolies. In order to minimize these problems and to regulate these markets, various rules have been set up and institutions and committees have been formed to implement these rules (Uğurlu, 2007: 30; Erol, 2003: 26).

The prevalence of regulation institutions in our country has two important roles. The emergence of these institutions is an indication of the end of the public sector in the economic structure, in other words, in the economic structure. Another situation is that the state starts to withdraw from the production site through the regulatory bodies. However, regulatory bodies require more budget size due to their role as a market inspector, even though they do not produce, and this results in more processing costs (Oğuz\&Çakmak, 2002). At this point, the form of intervention in the market is important. The extent and degree of intervention to the market; the role of regulation institutions is measured by the effect direction and amount. The social benefit of competition and activity-oriented regulation institutions in the market is higher than the social cost. Regulation institutions play an important role in the development of a country. Considering the current situation in our country, which is in the group of developing countries, we can say that the existence of economic regulation and its practitioners is overwhelming and necessary.

Under current conditions, we can make various predictions for the future by evaluating economic regulation in two aspects. Namely;

- In the near future, it would be correct to expect that these regulations will decrease with globalization. The advances in technology and the reduction in the cost of information transfer increase the cost of market differences between countries and encourage movements in the direction of deregulation. In the globalized world, we can say that deregulation will be earlier and faster in countries where it is possible to use the advantages of globalization more. As a matter of fact, the fact that developed countries are the pioneer in deregulation shows this. However, in developing countries, industries with higher access to international markets will tend to put more pressure on deregulation. privatization and opening up efforts to compete in Turkey will also be assessed in this framework right (Oğuz\&Çakmak, 2002). However, in the current situation, the trend in the western countries, deregulation direction, while the regulation in our country is just beginning to institutionalize, the transition to deregulation shows that the transition will be much more painful (Oğuz, 2011: 296). 
- In addition, the concept of regulation is primarily Assoc.d with the elimination of inefficiencies created by monopolies. The aim is to protect the consumers. In practice, it is widely used for the purpose of reaching political goals or for rent / interest exploration activities (Oğuz, 2011: 296). Therefore, the trend towards decreasing regulations is increasing. In addition to the use of regulations for rent / interest search activities; The tendency of globalization and regulation to be better calculated by the benefits and costs of this trend is strengthened (Oğuz\&Çakmak, 2002).

As a result, although economic regulation is seen as a remedy for economic inefficiency, the competition for regulation may lead to inefficiency by lowering the marginal social benefit expected from the regulation far below the marginal social costs (Parker, 2002: 499). Therefore, the implementation of economic regulation should be supported by policies appropriate to market interests, taking into account the internal dynamics and stakeholders of the sector.

\section{Conclusion}

When analyzed the economic regulation practices in Turkey, it is observed that there is a lack of regulation in point of economic activity and maintain its competitiveness. In the economically strong sectors (finance, capital, banking, energy, telecommunication and transport markets), the upper committees (CMB, BRSA, EMRA, BTK etc. $)^{5}$, which are the implementers of economic regulation;it is possible to say that they are not independent enough and cannot make effective decisions in-market competition, activity, pricing etc. In spite of their independent and autonomous structures.

In these key markets, it is important to design a system in order to achieve social benefit or public benefit by ensuring the co-ordination of public-private sector firms and consumer interests through the relevant regulatory bodies.

The limit of the duties and responsibilities undertaken by the regulatory institutions should be clarified by laws and rules in order to correct the disruptions of the market and to establish competition; these institutions should not be allowed to intervene in free market operation and in a way that would harm competition. For this purpose, the authority should be limited (in order to avoid overruns) and corporate accountability should be ensured.

Finally, the existing regulation, and especially economic regulation practices in Turkey -by taking into consideration the results of similar practices in other countries- in the context of "globalization, privatization and competition" phenomenon that today's prominent and directly affects the regulations should be revised and the most reasonable regulatory policies on a sectoral basis should be identified and implemented.

\footnotetext{
${ }^{5}$ Capital Markets Board (CMB), Banking Regulation and Supervision Agency (BRSA), Energy Market Regulatory Authority (EMRA), Information Technology and Communication Authority (ICTA)
} 


\section{References}

Akça, H. (2007). Regülasyon Ekonomisi, Adana, Nobel Kitabevi.

Ardıyok, Ş. (2002). Doğal Tekeller ve Düzenleyici Kurumlar, Türkiye Için Düzenleyici Kurum Modeli, Rekabet Kurumu Yayınları, Lisansüstü Tez Serisi No: 9, Ankara.

Çakal, R. (1996). Doğal Tekellerde Özelleştirme ve Regülasyon, DPT Uzmanlık Tezleri, Yayın No: 2455, Ankara.

Erol, M. (2003). Doğal Tekellerin Düzenlenmesi ve Telekomünikasyon Sektöründe Düzenleyici Kurum, DPT Uzmanlık Tezleri, Yayın No: 2680, Ankara.

Kirmanoğlu, H. (2011). Kamu Ekonomisi Analizi, Gözden Geçirilmiş ve Genişletilmiş 3.Baskı, İstanbul, Beta Basım Yayın Dağıtım.

Leibenstein, H. (1975). "Aspects of the X-Efficiency Theory of the Firm", The Bell Journal of Economics, Vol. 6 (2), pp. 580-606.

Leibenstein, H. (1966). "Allocative efficiency vs." X-efficiency"”, The American Economic Review, Vol. 56 (3), pp. 392-415.

Oğuz, F. (2011). Devlet ve Piyasa, Regülasyon Ekonomisine Giriş, Ankara, Seçkin Yayıncılık.

Oğuz, F. \& Çakmak O. (2002). "Küreselleşen Bir Dünyada Regülasyon”, Liberal Düşünce Dergisi, No: 7 (25-26), ss. 143-154.

Parker, D. (2002). "Economic regulation: a review of issues", Annals of Public and Cooperative Economics, Vol. 73 (4), pp. 493-519.

Pervan, N. (2006). Türkiye'de Doğalgaz Piyasasının Yeniden Yapılandırılması ve Sonuçları, Ankara Üniversitesi Sosyal Bilimler Enstitüsü, (Yayımlanmamış Yüksek Lisans Tezi), Ankara.

Sarısoy, S. (2010). “Düzenleyici Devlet ve Regülasyon Uygulamalarının Etkinliği Üzerine Tartışmalar”, Maliye Dergisi, No: 159, ss. 278-298.

Tepe, B. \& Ardıyok Ş. (2004). “Devlete Yeni Rol: Regülasyon”, Amme Idaresi Dergisi, No: 37 (1), ss. $105-130$.

Uğurlu, A. (2007). Bağımsız Düzenleyici Kuruluşlar ve Türkiye'de Enerji Sektöründe Uygulanması, Gazi Üniversitesi Sosyal Bilimler Enstitüsü, (Yayımlanmamış Yüksek Lisans Tezi), Ankara. 